\title{
EFEKTIFITAS PENERAPAN KOMBINASI MODEL PEMBELAJARAN PADA LATSAR CPNS DILINGKUNGAN PEMERINTAH PROVINSI RIAU
}

\author{
WELLIE ANNALIA \\ Badan Pengembangan Sumber Daya Manusia Provinsi Riau \\ E-mail : iingwellie@gmail.com
}

\begin{abstract}
ABSTRAK
Penelitian ini bertujuan untuk melihat sejauh mana efektifitas pembelajaran metoda ceramah yang dikombinasikan dengan model pembelajaran Window shopping dan Role Play terhadap mata pelatihan Etika Publik yang berada pada Agenda II (nilai-nilai ANEKA) pada Latsar CPNS di Lingkungan Pemerintah Provinsi Riau ( Kabupaten Rokan Hulu ). Penelitian ini merupakan Penelitian Tindakan Kelas terhadap peserta CPNS Latsar yang berjumlah 40 orang (1 kelas) dengan latar belakang pendidikan S1 dan sebahagian S2. Data kemampuan peserta mata pelatihan Etika publik dikumpulkan dengan menggunakan lembar observasi berupa pretest, komprehensif-test dan post-test yang terdiri dari satu kompetensi dan tiga sub kompetensi serta dibagi menjadi tiga indikator keberhasilan . Kombinasi model pembelajaran yang diberlakukan menggunakan kombinasi model pembelajaran ceramah interaktif, window shopping dan roleplay. Hasil analisis menunjukkan efektifitas kombinasi model pembelajaran pada pelatihan dasar CPNS dilingkungan Pemerintah Provinsi Riau dengan hasil nilai post-test pada kelas C $95 \%$ mendapat nilai memuaskan hingga sangat memuaskan
\end{abstract}

Kata Kunci : Latsar, CPNS, ANEKA ,Ceramah interaktif, Window Shopping, Role Play, Pre-Test, Komprehensif-Test, Post -Test

\section{PENDAHULUAN}

Undang-Undang No 5 Tahun 2014 tentang Aparatur Sipil Negara mengamanatkan Instansi Pemerintah untuk wajib memberikan Pendidikan dan Pelatihan (Diklat) terintegrasi bagi Calon Pegawai Negeri Sipil (CPNS) selama 1 (satu) tahun masa percobaan. Tujuan dari Diklat terintegrasi ini adalah untuk membangun integritas moral, kejujuran, semangat dan motivasi nasionalisme dan kebangsaan, karakter kepribadian yang unggul serta dapat bertanggungjawab, dan memperkuat profesionalisme serta kompetensi dibidangnya. Dengan demikian UU ASN mengedepankan penguatan nilai-nilai dan pembangunan karakter dalam mencetak PNS.

Mata Diklat Etika Publik memfasilitasi pembentukan nilai-nilai dasar etika publik pada peserta Diklat melalui pembelajaran kode etik dan perilaku pejabat publik, bentuk-bentuk kode etik dan implikasinya, aktualisasi kode etik PNS. Mata Diklat ini disajikan berbasis experiencial learning, dengan penekanan pada proses internalisasi nilai-nilai dasar tersebut dan keberhasilan peserta dinilai dari kemampuannya mengaktualisasikan nilai-nilai dasar etika dalam mengelola pelaksanaan tugas jabatannya. Kompetensi dasar yang ingin dicapai setelah mengikuti pembelajaran ini, peserta diharapkan mampu menanamkan nilai dan membentuk sikap dan perilaku patuh kepada standar etika publik yang tinggi.

Selama pelaksanaan pelatihan peserta berposisi ditempat diklat (on campus) dan off campus (masa habituasi /pelaksanaan aktualisasi) disamping mendapat pembekalan dikelas peserta juga mendapatkan pelatihan sikap perilaku dari sisi disiplin, mental, karakter dan lain lain yang dijalani peserta dari pukul 06. 00 pagi hingga 09.00 malam dan kalau ada caraka malam selesainya mendekati tengah malam begitu juga pengerjaan tugas akan dikerjakan pada saat malam hari karena dari pagi hingga sore on class. Pada saat menghadapi pembekalan dikelas terlihat kecendrungan sebagian peserta "kurang bisa berkonsentrasi secara penuh". Kemungkinan Pembekalan yang disampaikan tidak sampai kepeserta sebagai mana seharusnya dengan pembekalan yang disampaikan biasanya berupa ceramah interaktif kemudian diberi penugasan dan terlihat dengan hasil yang dicapai relative sedikit diatas rata rata. 


\section{METODE PENELITIAN}

Penulis melaksanakan Penelitian Tindakan Kelas dengan objek penelitian yaitu peserta Pelatihan Dasar Calon Pegawai Negeri Sipil di Lingkungan Pemerintah Provinsi Riau (Kabupaten Rokan Hulu) terhadap 1 (satu) kelas berjumlah 40 (empat puluh) orang/kelas Y dengan latar belakang pendidikan yang sama yaitu S1 dan ada beberapa yang S2. Untuk melihat perbandingan penulis juga sudah melakukan dikelas CPNS Rohul sebelumnya dengan kondisi sama pengamatan dengan menggunakan obsevasi dengan menggunakan pre-test pada awal masuk kemudian Komprehensif-test ditengah dan komprehensif-test (metode penyampaian pembekalan belum menggunakan kombinasi model pembelajaran tidak hanya cermah interaktif) dan datanya akan penulis tampilkan dengan menggunakan nama kelas X. Sedangkan yang penulis akan lakukan saat ini adalah melakukan kombinasi model pembelajaran dengan Metoda ceramah interaktif pada saat pembekalan mata pelatihan Etika Publik. Penelitian dilakukan setelah Penulis melaksanakan pembekalan awal mengenai Deskripsi Mata Pelatihan, Kompetensi Dasar dan Indikator Keberhasilan dengan metode/ model pembelajaran interaktif pada kelas $\mathrm{Y}$ sama dengan yang penulis lakukan di kelas $\mathrm{X}$ sebelumnya didapatkan hasil sebagai berikut :

Penelitian dimulai pada jam pelajaran ke 3 dengan mengikuti kaidah bagan dibawah ini

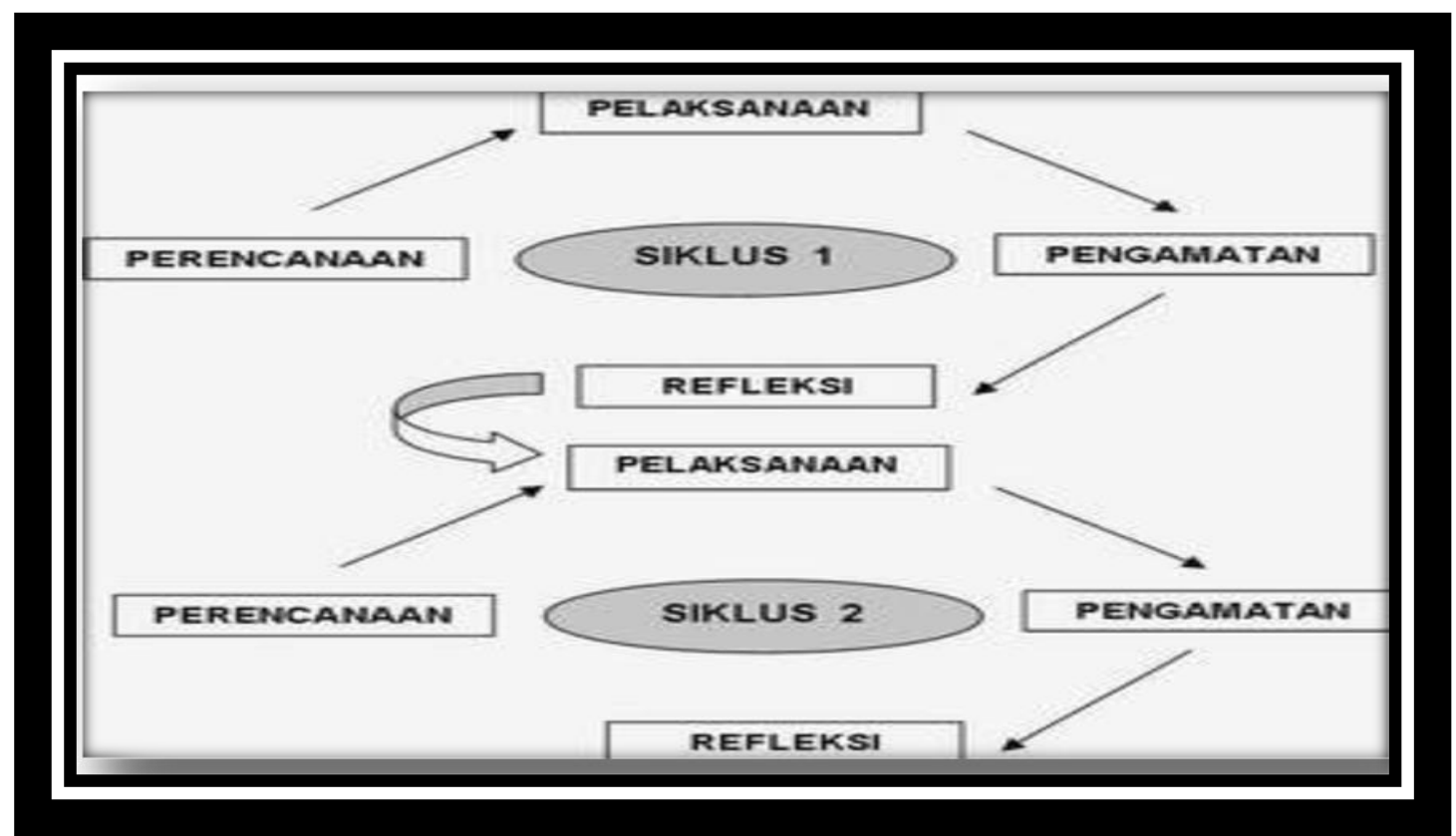


Vol. 1 No. 1 Mei 2021

\section{Gambar 1. Bagan Penelitian Tindakan Kelas}

Bagan Penelitian Tindakan Kelas diadopsi dari Stephen Kemmis dan Mc. Taggart (1998) dengan menggunakan dua siklus, dengan masing-masing siklus terdiri dari empat tahapan yaitu: (1) perencanaan, (2) tindakan, (3) observasi dan evaluasi, dan (4) refleksi dan diadaptasikan pada penelitian ini. (Pada siklus pertama (siklus I) siklus proses pembelajaran menggunakan model pembelajaran Window Shopping dengan menambahkan sub bagian pada disain pembelajaran pada Rancang Bangun Pembelajaran Mata Diklat dan Rencana Pembelajaran 1) Peneliti mengkondisikan kelas atas 8 (delapan) kelompok dimana masingmasing kelompok terdiri dari 5 (lima) peserta dimana masing-masing kelompok memaparkan 1 slide dari power point pengampu yang merupakan kunci kunci mata pelatihan Etika Publik.

2) Dimana pelaksanaan Window Shopping langsung dilaksanakan oleh ke 8 kelompok dimana 5 (lima) peserta permasing masing kelompok, 1 (satu) orang menjaga "lapak/ gawangnya)/ salah satu kunci mata pelatihan Etika Publik yang dituliskan sebelumnya pada lembaran karton dengan spidol dan yang lainnya " berbelanja "ke lapak / gawang kelompok yang lainnya. 3) Setelah dilaksanakan model pembelajaran tersebut dilaksanakan komprehensif test 4) Tahap ini melihat hasil dari komprehensif-test Tahapan ini dimaksudkan untuk mengkaji secara menyeluruh tindakan yang telah dilakukan, berdasarkan data yang telah terkumpul, kemudian dilakukan evaluasi guna menyempurnakan tindakan berikutnya. Refleksi dalam PTK mencakup analisis, sintesis, dan penilaian terhadap hasil pengamatan atas tindakan yang dilakukan. Jika terdapat masalah dari proses refleksi maka dilakukan proses pengkajian ulang melalui siklus berikutnya yang meliputi kegiatan pembekalan lebih "mengerucut dengan model pembekalan Role play (bermain peran )

Pada pelaksanaan siklus kedua (siklus II) adalah proses pembelajaran menggunakan model pembelajaran Role Play yang dilakukan pada siklus ini dengan menambahkan sub bagian pada disain pembelajaran pada Rancang Bangun Pembelajaran Mata Diklat dan Rencana Pembelajaran : tahap 1) Model Pembelajaran Role Play yang digunakan pada proses belajar mengajar ini dengan membagi peserta atas 4 (empat) kelompok dimana masing masing kelompok memaparkan 1 (satu) contoh kasus yang ada dimodul Etika Publik dari LAN 2) Dimana masing msing kelompok memainkan peran sesuai kasus yang dimaksud. Setelah dilaksanakan model pembelajaran tersebut dilaksanakan Post Test 3) Tahap ini melihat hasil dari komprehensif test 4) melakukan refleksi tentang hasil aktivitas belajar peserta didik selama proses pembelajaran dan post tes (tes hasil belajar) pada akhir siklus

\section{HASIL PENELITIAN DAN PEMBAHASAN}

Tabel 1. Hasil Pre-test

\begin{tabular}{|l|l|l|l|l|}
\hline $\begin{array}{l}\text { Rentang } \\
\text { Nilai }\end{array}$ & \multicolumn{2}{|c|}{ Kelas X } & \multicolumn{2}{c|}{ Kelas Y } \\
\cline { 2 - 6 } & Jumlah Peserta (orang) & $\begin{array}{l}\text { Persentas } \\
\text { e }\end{array}$ & Jumlah Peserta (orang ) & Persentase \\
\hline $\mathbf{0 - 1 0}$ & 15 & $37,5 \%$ & 18 & $45 \%$ \\
\hline $\mathbf{1 1 - 2 0}$ & 9 & $22,5 \%$ & 11 & $27,5 \%$ \\
\hline $\mathbf{2 1 - 3 0}$ & 12 & $30 \%$ & 7 & $17,5 \%$ \\
\hline $\mathbf{3 1 - 4 0}$ & 0 & $0 \%$ & 1 & $2,5 \%$ \\
\hline $\mathbf{4 1 - 5 0}$ & 4 & $10 \%$ & 3 & $7,5 \%$ \\
\hline $\mathbf{5 1 - 6 0}$ & - & - & - & - \\
\hline $\mathbf{6 1 - 7 0}$ & - & - & - & - \\
\hline $\mathbf{7 1 - 8 0}$ & - & - & - & - \\
\hline $\mathbf{8 1 - 9 0}$ & - & - & - & - \\
\hline $\mathbf{9 1 - 1 0 0}$ & - & - & - & - \\
\hline
\end{tabular}




\begin{tabular}{|l|l|l|l|l|}
\hline Jumlah & 40 orang & $100 \%$ & 40 orang & $100 \%$
\end{tabular}

Dilihat dari Tabel 1 Hasil Pre-Test bahwa $100 \%$ baik kelas X maupun Kelas Y prosentase

nilai yang didapat antara $<60$ dengan kualifikasi sangat rendah.

\section{Siklus I pertemuan pertama}

Pelaksanaan siklus I dilaksanakan pada saat pembekalan mata pelatihan Etika Publik pada saat pembekalan di jam pelajaran ke 3 (Untuk jam pelajaran 1 tetap menggunakan model pembelajaran ceramah interaktif seperti sebelumnya.) Pada Siklus ini dilaksanakan pembekalan dengan memberikan peran serta peserta yaitu proses pembelajaran menggunakan model pembelajaran Window Shopping sesuai dengan skema yang telah ditetapkan dilakukan beberapa tahapan: tahap (1) Peneliti mengkondisikan kelas atas 8 (delapan) kelompok dimana masing kelompok terdiri dari 5 (lima) peserta dimana masing masing kelompok memaparkan 1 slide dari power point pengampu yang merupakan kunci kunci mata pelatihan Etika Publik. 2) Dimana dari 5 (lima) peserta permasing masing kelompok 1 (satu) orang menjaga " lapak / gawangnya)/ salah satu kunci mata pelatihan Etika Publik yang dituliskan pada selembar karton dengan spidol dan yang lainnya " berbelanja " ke lapak / gawang kelompok yang lainnya.

\section{Siklus I pertemuan kedua}

Pelaksanaan kedua dilaksanakan pada jam pelajaran ke 4 dimana peneliti. Setelah dilaksanakan model pembelajaran tersebut dilaksanakan komprehensif tes melihat hasil dari komprehensif-test Tahapan ini seperti dibawah ini. Model Pembelajaran Window Shopping yang digunakan pada proses belajar mengajar ini dengan membagi peserta atas 8 (delapan) kelompok dimana masing masing kelompok memaparkan 1 slide dari power point pengampu yang merupakan kunci kunci mata pelatihan Etika Publik. Dimana dari 5 (lima) peserta permasing masing kelompok 1 (satu) orang menjaga " lapak / gawangnya)/ salah satu kunci mata pelatihan Etika Publik yang dituliskan pada selembar karton dengan spidol dan yang lainnya " berbelanja " ke lapak / gawang kelompok yang lainnya.

Setelah dilaksanakan model pembelajaran tersebut dilaksanakan Komprehensif-test didapatkan hasil sebagai berikut :

Tabel 2. Hasil Komprehensif Test

\begin{tabular}{|c|c|c|c|c|}
\hline \multirow[t]{2}{*}{ Nilai } & \multicolumn{2}{|l|}{ Kelas X } & \multicolumn{2}{|c|}{ Kelas Y } \\
\hline & Jumlah Peserta (orang ) & Persentase & Jumlah Peserta (orang ) & Persentase \\
\hline $0-10$ & - & - & - & - \\
\hline $11-20$ & - & - & - & - \\
\hline $21-30$ & & & - & - \\
\hline $31-40$ & & & - & - \\
\hline $41-50$ & 7 & $17,5 \%$ & - & - \\
\hline $51-60$ & 5 & $12,5 \%$ & 1 & $2,5 \%$ \\
\hline $61-70$ & 13 & $32,5 \%$ & 1 & $2,5 \%$ \\
\hline $71-80$ & 8 & $20 \%$ & 7 & $17,5 \%$ \\
\hline $81-90$ & 5 & $12,5 \%$ & 10 & $25 \%$ \\
\hline $91-100$ & 2 & $5 \%$ & 21 & $52,5 \%$ \\
\hline Jumlah & 40 orang & $100 \%$ & 40 orang & $100 \%$ \\
\hline
\end{tabular}

Dilihat dari Tabel 2 Hasil Komprehensif-Test bahwa ada efektifitas kombinasi model pembelajaran pada kelas Y dimana:

1. Pada kelas $X$ yang nilainya berada dibawah 61 (sangat kurang) ada 12 orang ( 30

$\%)$ pada kelas Y ada 1 orangan $(2,5 \%$. 
2. Untuk nilai 61-70 ( kurang ) pada kelas X 13 orang (32,5\%) untuk kelas Y ada 1 orang $(2,5 \%)$

3. Untuk nilai 71-80 ( Cukup ) pada kelas X ada 8 orang( $20 \%$ ) dan kelas Y terdapat 7 orang $(17,5 \%)$

4. Untuk nilai 81-90 ( memuaskan ) pada kelas $\mathrm{X}$ ada 5 orang ( $12,5 \%)$ dan kelas $\mathrm{Y}$ ada 10 Orang ( $25 \%)$

5. Untuk nilai 91-100 ( sangat memuaskan ) pada kelas X ada 2 orang ( $5 \%$ ) dan pada kelas Y ada 21 Orang ( $52,5 \%)$

\section{Siklus II Pertemuan Pertama}

Pada saat proses belajar mengajar dibagian mendekati akhir untuk kelas X tetap melaksanakan proses belajar mengajar tetap hanya menggunakan model pembelajaran ceramah interaktif (seperti yang sudah disampaikan diawal) sedangkan untuk kelas Y pada proses belajar mengajar menggunakan model pembelajaran Role Play. Model Pembelajaran Role Play yang digunakan pada proses belajar mengajar ini dengan membagi peserta atas 4 (empat) kelompok dimana masing-masing kelompok memaparkan 1 (satu) contoh kasus yang ada dimodul Etika Publik dari LAN. Dimana masing-masing kelompok memainkan peran sesuai kasus yang dimaksud. Setelah dilaksanakan model pembelajaran tersebut dilaksanakan Post-Test didapatkan hasil sebagai berikut :

\section{Siklus II Pertemuan Kedua}

Pelaksanaan kedua dilaksanakan pada jam pelajaran ke 4 dimana peneliti. Setelah dilaksanakan model pembelajaran tersebut dilaksanakan Post-test melihat hasil dari Komprehensif-test Tahapan ini seperti dibawah ini

Tabel 3. Hasil Post Test

\begin{tabular}{|l|l|l|l|l|}
\hline \multirow{2}{*}{ Nilai } & \multicolumn{2}{|c|}{ Kelas X } & \multicolumn{2}{c|}{ Kelas Y } \\
\cline { 2 - 6 } & Jumlah Peserta (orang) & Persentase & Jumlah Peserta (orang ) & Persentase \\
\hline $\mathbf{0 - 1 0}$ & - & - & - & - \\
\hline $\mathbf{1 1 - 2 0}$ & - & - & - & - \\
\hline $\mathbf{2 1 - 3 0}$ & - & - & - & - \\
\hline $\mathbf{3 1 - 4 0}$ & - & - & - & - \\
\hline $\mathbf{4 1 - 5 0}$ & - & - & - & - \\
\hline $\mathbf{5 1 - 6 0}$ & & - & - & - \\
\hline $\mathbf{6 1 - 7 0}$ & 7 & $17,5 \%$ & - & - \\
\hline $\mathbf{7 1 - 8 0}$ & 20 & $50 \%$ & 2 & $5 \%$ \\
\hline $\mathbf{8 1 - 9 0}$ & 9 & $22,5 \%$ & 5 & $12,5 \%$ \\
\hline $\mathbf{9 1 - 1 0 0}$ & 4 & $10 \%$ & 33 & $82,5 \%$ \\
\hline Jumlah & 40 orang & $100 \%$ & 40 orang & $100 \%$ \\
\hline
\end{tabular}

Dilihat dari Tabel 2 Hasil Komprehensif-Test bahwa ada efektifitas kombinasi model pembelajaran pada kelas Y dimana:

1. Untuk nilai 61-70 ( kurang ) pada kelas $X 7$ orang (17,5\%) untuk kelas Y tidak ada

2. Untuk nilai 71-80 (Cukup ) pada kelas $X$ ada 20 orang( $50 \%$ ) dan kelas Y terdapat 2 orang $(5 \%)$

3. Untuk nilai 81-90 ( memuaskan ) pada kelas X ada 9 orang (22,5\%) dan kelas Y ada 5 Orang ( $12,5 \%)$

4. Untuk nilai 91-100 ( sangat memuaskan ) pada kelas $\mathrm{X}$ ada 4 orang ( $10 \%$ ) dan pada kelas Y ada 33 Orang ( 82,5 \%) 
Yang menjadi objek Penelitian adalah Peserta Latsar (Pelatihan Dasar) Calon Pegawai Negeri Sipil (CPNS) yang berada dilingkuangan Pemerintah Provinsi Riau ( Kabupaten Rokan Hulu ). Pada tanggal 23 dan 25 Oktober 2019 sebelum dilaksanakan penelitian, Penulis telah melaksanakan pengamatan dengan menggunakan 3 alat test seperti pembekalan yang umumnya dilakukan di Diklat Latsar yaitu Pre-Test, Komprehensif-Test dan Post-Test dengan metode/model Pembelajaran hanya menggunakan ceramah Interaktif didapatkan hasil untuk Komprehensif-Test.

Dan pada saat penulis meilaksanakan penelitian Tindakan pada tanggal 30 sampai dengan 31 Oktober 2019 penulis mengkombinasikan model/metode pembelajaran yang biasa digunakan pada pelatihan latsar dengan model pembelajaran Window shopping dan Role Play dengan alat test yang sama dengan yang sebelumnya yaitu Pre-Test, Komprehensif-test dan Post-Test. Dan didapatkan peningkatan yang signifikan

Seperti diketahui Blight dalam Hisyam Zaini, Bermawy Munthe, Sekar ayu Aryani berpendapat bahwa sesuai dengan bukti penelitian yang dilakukan di Amerika Serikat. mempunyai kelemahan kelemahan dari metode ceramah:

a. Instruktur lebih aktif sedangkan peserta pasif karena perhatian hanya terpusat pada guru.

b. Peserta seakan diharuskan mengikuti segala apa yang disampaikan oleh instruktur, meskipun peserta ada yang bersifat kritis karena instruktur dianggap selalu benar.

c. Peserta akan lebih bosan dan merasa mengantuk, karena dalam metode ini, hanya Instruktur yang aktif dalam proses belajar mengajar, sedangkan para peserta didik hanya duduk diam mendengarkan penjalasan yang telah diberikan oleh instruktur.

Salah satu usaha guru untuk menciptakan agar hasil belajar maksimal adalah melalui model pembelajaran Window Shopping (WS). model pembelajaran WS terdapat kegiatan siswa berjalan-jalan melihat- lihat hasil pekerjaan kelompok lain. Namun demikian siswa yang berkunjung bukan berarti tidak mendapat apa-apa. Siswa yang berkunjung akan mendapatkan ilmu. Dalam model pembelajaran WS siswa tidak hanya melihat-lihat hasil pekerjaan kelompok lain tetapi juga mencatat hasil pekerjaan tersebut untuk saling berbagi dengan anggota kelompoknya. Setiap anggota yang berkunjung juga berbelanja ilmu untuk oleh-oleh anggota lainnya khususnya anggota yang bertugas sebagai "penjaga toko". Model pembelajaran ini lebih baik jika disertai dengan pendekatan Jelajah Alam Sekitar (JAS).

Menurut Anisa (2018 dkk) pendekatan JAS merupakan pendekatan pembelajaran yang memanfaatkan lingkungan alam sekitar kehidupan peserta didik baik lingkungan fisik, sosial, maupun budaya sebagai objek belajar biologi yang fenomenanya dipelajari melalui kerja ilmiah. Pendekatan ini menekankan pada kegiatan pembelajaran yang dikaitkan dengan situasi dunia nyata, sehingga selain dapat membuka wawasan berpikir yang beragam dari seluruh peserta didik, pendekatan ini memungkinkan peserta didik dapat mempelajari berbagai konsep dan cara mengkaitkannya dengan kehidupan nyata sehingga hasil belajarnya lebih berdaya guna bagi kehidupannya.

Pendekatan JAS tidak mengharuskan siswa menghafal informasi, tetapi mendorong siswa untuk mengembangkan informasi pengetahuan yang diperoleh berdasarkan konsep biologi melalui proses eksplorasi di lingkungan sekitar. Pendekatan JAS merupakan pendekatan pembelajaran yang didalam kegiatannya memanfaatkan objek khususnya lingkungan sekitar secara langsung melalui kegiatan pengamatan, diskusi dan laporan hasil .

Ada beberapa keunggulan dengan menggunakan metode role playing, di antaranya adalah:

a. Dapat berkesan dengan kuat dan tahan lama dalam ingatan siswa. Disamping merupakan pengalaman yang menyenangkan yang sulit untuk dilupakan.

b. Sangat menarik bagi siswa, sehingga memungkinkan kelas menjadi dinamis dan penuh antusias.

c. Membangkitkan gairah dan semangat optimisme dalam diri siswa serta menumbuhkan rasa kebersamaan. 
d. Siswa dapat terjun langsung untuk memerankan sesuatu yang akan di bahas dalam proses belajar.

Role play banyak digunakan dalam bidang psikologi, bidang pendidikan, bidang komunikasi dan kemudian diadopsi oleh teater sebagai metode pelatihan calon pemeran. Metode ini memiliki kelebihan yang tidak dimiliki oleh metode lain. Kelebihan metode roleplay adalah: a. Media belajar kerjasama antar personal b. Media belajar bahasa yang baik dan benar c. Peserta bisa mengambil keputusan dengan cepat dan berekspresi secara utuh d. Media evaluasi pengalaman pada waktu permainan berlangsung e. Memberi kesan yang kuat dan tahan lama dalam ingatan f. Memberi pengalaman yang menyenangkan g. Membangkitkan gairah dan semangat optimis dalam diri peserta $h$. Menumbuhkan rasa kebersamaan dan kesetiakawanan sosial yang tinggi i. Peserta dapat menghayati peristiwa yang berlangsung dengan mudah dan dapat memetik makna yang terkandung dalam permainan tersebut $\mathrm{j}$. Meningkat kemampuan profesional peserta

\section{PENUTUP}

Berdasarkan hasil Penelitian maka didapatkan adanya efektifitas Kombinasi Model Pembelajaran yaitu Ceramah Interaktif, Window Shopping dan Role Play pada Latsar CPNS dilingkungan Pemerintah Provinsi Riau (Kabupaten Rokan Hulu) didapatkan hasil yang signifikan yaitu untuk nilai 81-90 (memuaskan) kelas Y ada 5 Orang (12,5\%) dan untuk nilai 91-100 (sangat memuaskan) pada kelas $\mathrm{Y}$ ada 33 Orang $(82,5 \%)$ yang semula dengan pengamatan biasa dengan pemberlakuan alat test yang sama tetapi tanpa kombinasi model pembelajaran didapatkan untuk nilai 81-90 (memuaskan) pada kelas $X$ ada 9 orang $(22,5 \%)$ dan untuk nilai 91-100 (sangat memuaskan) pada kelas X ada 4 orang (10\%)

\section{DAFTAR PUSTAKA}

Dough Lennick \& Fred Kiel, Phd. 2005. Moral Intelligence. New York, Wharton School Publishing.

Douglas, Paul. (1993). Ethics in Government. Cambridge, Harvard University Press.

Erie Sudewo. (2011). Best Practice Character Building Menuju Indonesia Lebih Baik. Jakarta, Penerbit Republika.

Frederickson, George H. \& David K. Hart. (1985). "The Public Service and the Patriotism of Benevolence", Public Administration Review, September - October.

Haeli. (2019) Berbelanja Ilmu dengan Metoda Pembelajaran “Window Shopping”, BPSDM News

Haryatmoko. (2011). Etika Publik. Jakarta, PT Gramedia PustakaUtama.

Kumorotomo, Wahyudi. (2014). Etika Administrasi Negara. Jakarta, Penerbit Rajagrafindo Persada.

Modul Etika Publik Pendidikan dan Pelatihan Prajabatan Golongan III (2015), Lembaga Administrasi Negara, Jakarta.

Nanus, Burt. (1992). Visionary Leadership: Creating a Compelling Sence of Direction fAnnisaor your organization, Jossey-Bass.

Raymond W.Cox III. (2009). Ethics and Integrity in Public Administration, M.E. Sharpe, Inc. Savira, Annisa N dkk, (2018), Peningkatan Minat Belajar siswa dengan menggunakan metoda ceramah interaktif, Jurnal IAIN Kediri

Subagyo, Heru. (2013), Role Play, Kementerian Pendidikan dan Kebudayaan, Jakarta

Undang-Undang Nomor 5 Tahun 2014 tentang Aparatur Sipil Negara;

Yudi Latif. (2011). Negara Paripurna. Jakarta, PT. Gramedia

Zumroh, Nur ( 2018) Model Pembelajaran Window Shooping dan pendekatan Jelajah Alam Sekitar pada materi Ekosistem di Madrasah Aliya Salafiah ,Pati Jawa Tengah, Universitas Negeri Semarang . 